\title{
OCCURRENCE OF THE DROSOPHILA FLAVOPILOSA SPECIES GROUP (DIPTERA, DROSOPHILIDAE) IN THE STATE OF SÃO PAULO (BRAZIL) WITH DESCRIPTION OF ONE NEW SPECIES.
}

CARLOS RIBEIRO VILELA

\section{ABSTRACT}

One new Brazilian species of Drosophila belonging to the nesiota subgroup of the flavopilosa group, which is recorded for the first time from the State of São Paulo, is illustrated and described as D. mariaehelenae, sp. nov. It has been found breeding on flowers of Cestrum intermedium Sendtn., together with D. cestri Brncic, D. cordeiroi Brncic, D. cordeiroi Brncic, D. flavopilosa Frey and D. incompta Wheeler \& Takada, Zygothrica vittimaculosa Burla and one undetermined species of the Drosophila tripunctata species group. Photographs are provided of the male genitalia of the first four species.

The Drosophila flavopilosa species group, currently comprising 11 described species, was proposed by Wheeler, Takada \& Brncic in 1962. Sixteen years later (Brncic, 1978), it was reported for the first time from Brazil, State of Rio Grande do Sul, where four species were collected: D. cestri Brncic, D. cordeiroi Brncic, D. flavopilosa Frey and D. incompta Wheeler \& Takada.

The traditional method of collecting Drosophila by baiting with fermented fruits never or rarely yields adult specimens of the flavopilosa group, which may be collected by sweeping Cestrum bushes or by breeding them out of their flowers. Having this in mind and following the suggestion of Dr. D. Brncic, I started, in 1978, searching for blooming Cestrum plants in the hope that I could find specimens of the flavopilosa group which had never been collected in the State of São Paulo.

In May of 1982, I finally found in the vicinities of Santa Izabel (SP) one blooming tree of Cestrum intermedium Sendtn. (Solanaceae). Many branches bearing 2,835 flowers in several stages of development were broken off the plant and kept in eight bottles of $250 \mathrm{ml}$ containing moist sand and plugged with gauze-wrapped cotton.

Emerged flies were removed daily for examination. The male and female genitalia were the main characters used to distinguish among the Drosophilidae species. No attempts were made to identify the microhymenoptera and non-drosophilid Diptera specimens which were also reared from the flowers. 
Six species of Drosophilidae have emerged in a 15-day period (table I): one new species of the flavopilosa group (Fig. la) which is described below, D. incompta (Fig. 1b), D. cordeiroi (Fig. lc), D. cestri (Fig. ld), one undetermined species of the Drosophila tripunctata species group and Zygothrica vittimaculosa Burla.

The previous observations by Wheeler et al. (1962) and Brncic (1978) that many species of the flavopilosa group have been usually taken together at one given locality are confirmed in the present paper.

The insects are deposited in the «Museu de Zoologia da Universidade de São Paulo (MZUSP)», São Paulo, and one dried specimen of the host plant (Cestrum intermedium) is in the herbarium of the «Departamento de Botânica (SPE, n 30.456), Instituto de Biociências, Universidade de São Paulo», São Paulo.

In preparing the male and female genitalia I followed Wheeler \& Kambysellis, 1966. The terminology used for the male genitalia is modified after Hsu, 1949 and Kaneshiro, 1969; for details see Vilela, 1983.

\section{T A B LE I \\ Emergence date}

$\begin{array}{lllllllllll}19 & 2021 & 22 & 23 & 24 & 25 & 26 & 28 & 31 & 04 & 07 \\ \text { total }\end{array}$

\section{Drosophila cestri}

D. corderoi

D. incompta

D. mariaehelenae, sp. nov.

unidentified species of tripunctata group

Zygothrica vittimaculosa

Total

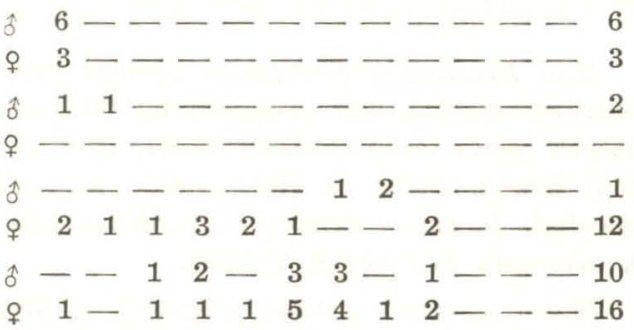

Table I - Species of Drosophilidae bred out in the laboratory, in May-June 1982, from flowers of Cestrum intermedium Sendtn. (Solanaceae) collected at $11 \mathrm{Km} \mathrm{NE}$ of Santa Izabel, São Paulo, Brazil on 08.V.1982.

Drosophila (Drosophila) mariaehelenae, sp. nov. (Figs. 1a; 2; 3)

Type-material - Holotype male, labelled: «BRASIL - SP, $11 \mathrm{Km}$ NE of Santa Izabel, 23017'S, 46012'W, C. R. Vilela \& M. H. A. Ribeiro col. / Bred on 22.V.1982 from flower of Cestrum intermedium collected on 08.V.1982 / HOLOTIPO Drosophila mariaehelenae $\hat{\jmath} \gg$. Twenty-five paratypes ( $9 \hat{\delta}, 16$ $ᄋ$ ): same data as holotype, except breeding date (see table I); all specimens in MZUSP (São Paulo). The postabdomen of the holotype and 3 paratypes $(2 \hat{o}, 1$ o $)$ has been removed, dis- 


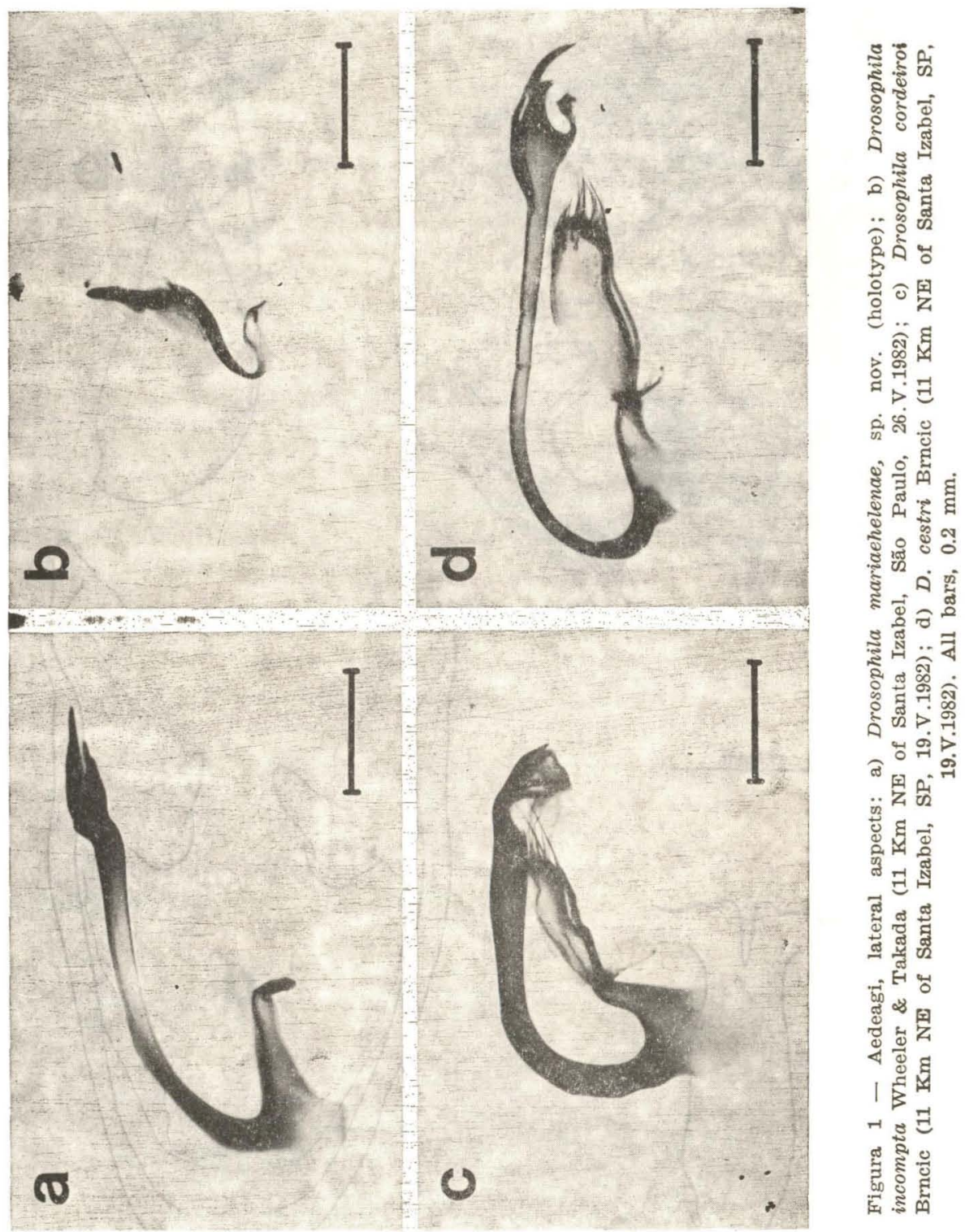




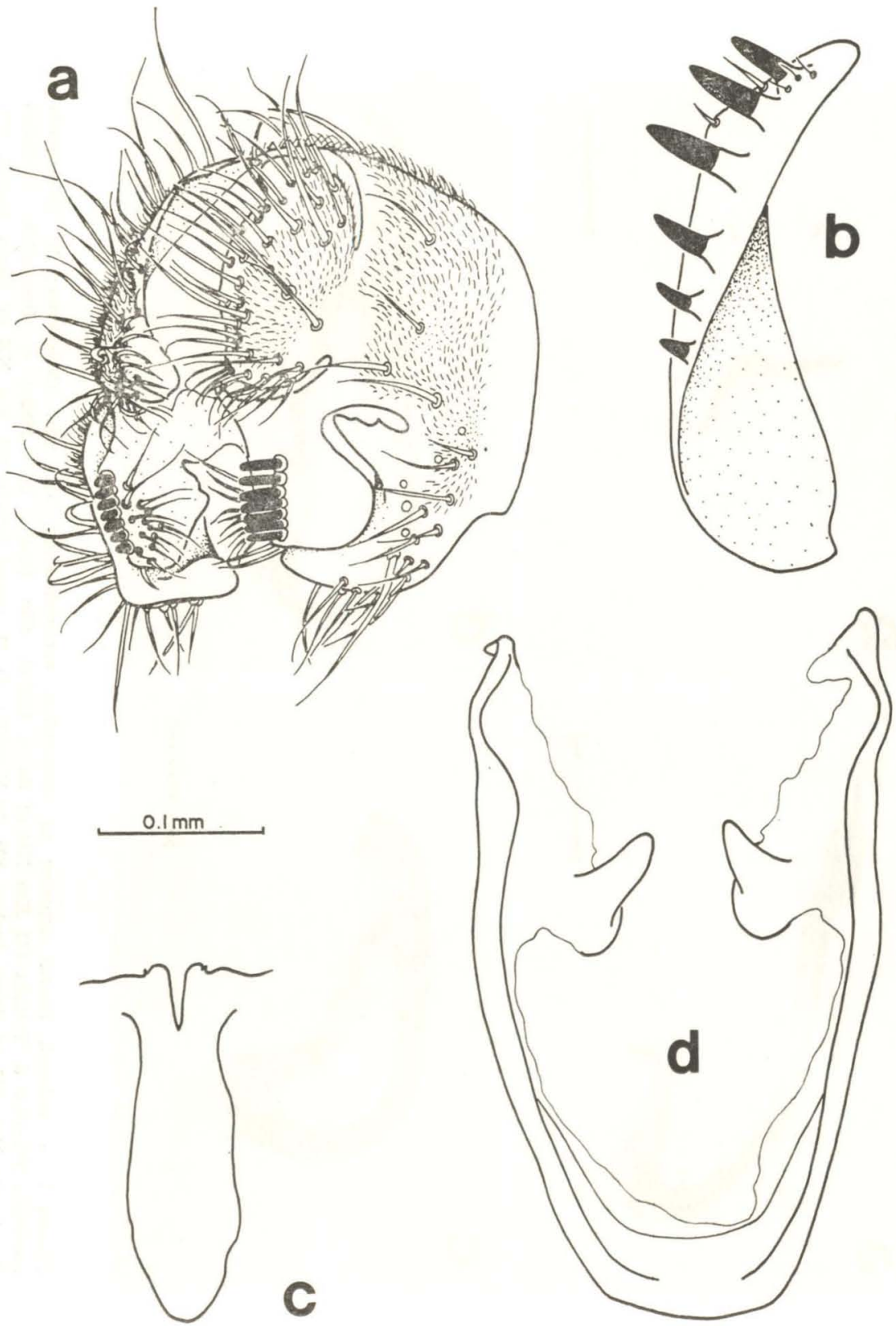

Figura 2 - Drsophila mariaehelenae, sp. nov. (holotype): a) external male genitalia, lateroblique, aspect; b) ovipositor, lateral aspect; c) bridge, posterior aspect; d) hypandrium, posterior aspect. 


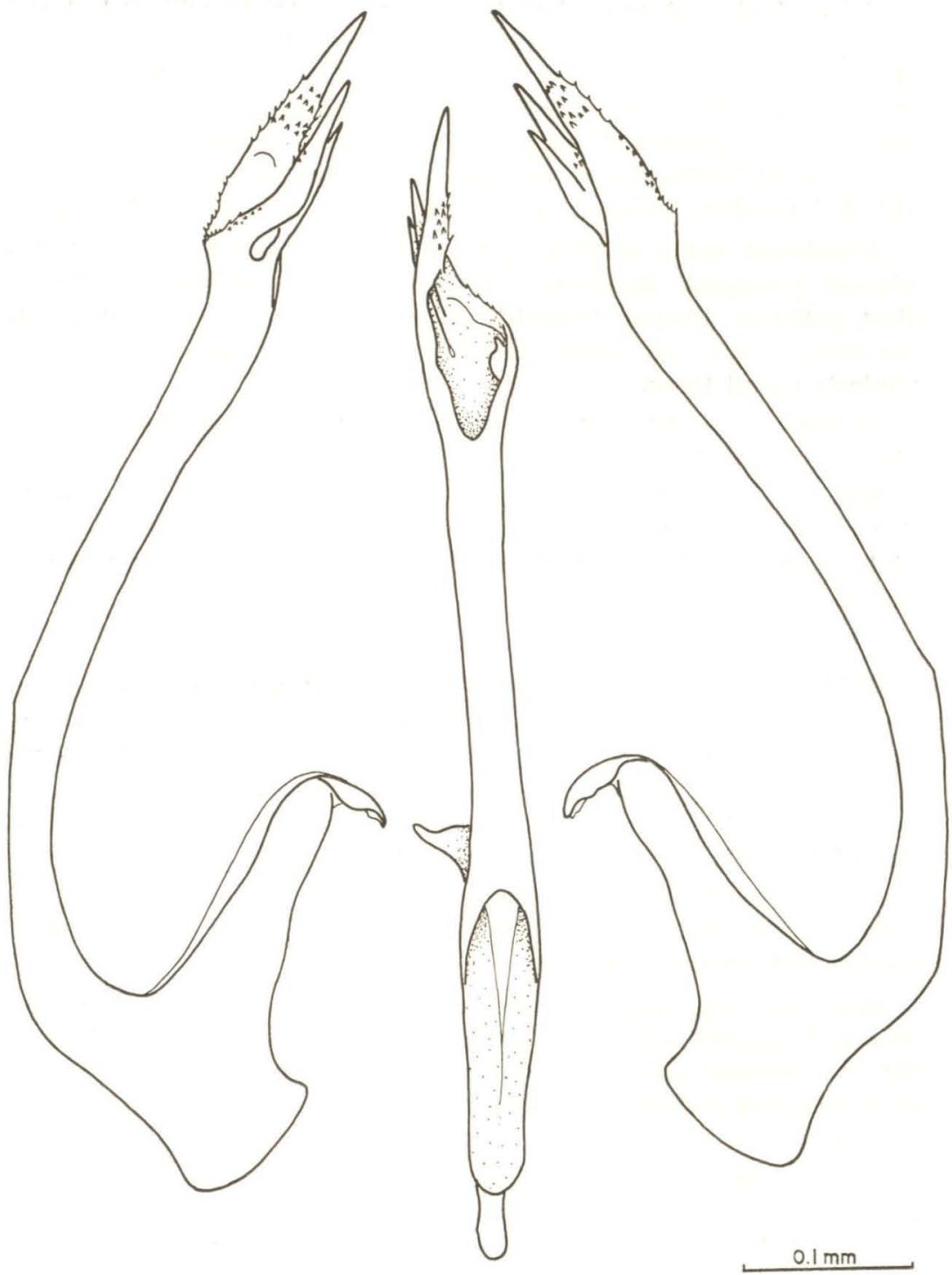

Figura 3 - Drosophila mariaehelenae, sp. nov. (holotype): aedeagus, three aspects. 
sected and the parts placed in an attached microvial. Type-locality: Chácara Santa Mônica, $11 \mathrm{Km} \mathrm{NE}$ of Santa Izabel (2317'S, 46¹2'W), São Paulo, Brazil.

External characters of imagines $\hat{0}$, $q$ - Arista with 3-4 dorsal and 2 ventral branches plus terminal fork; hair-like branches present. Antennae yellow. Front yellow, pollinose. Middle orbital about $1 / 2$ of cnterior and $1 / 3$ of posterior. Only one prominent oral bristle. Face yellow. Carina prominent, narrow, not sulcate, yellow. Palpi yellow, pollinose, with bristles on ventral surface. Cheeks yellow, their greatest width 1/5 greatest diameter of eyes. Eyes red, with short black piles.

Acrostichal hairs in 6 irregular rows. No prescutellars. Anterior scutellars divergent. Mesonotum brownish yellow, pollinose. Scutellum yellow, pollinose. Pleurae brownish yellow. Sterno index about 0.6. Haltəres yellow. Legs pale yellow. Apical bristles on first and second tibiae, preapicals on all three.

Abdomen brownish yellow, without any definite darkening on posterior margins of tergites.

Wings clear. Costal index about $4.1 ; 4$ th vein index about $1.8 ; 5 \mathrm{x}$ index about $1.4 ; 4 \mathrm{c}$ index about $0.6 ; \mathrm{M}$ index about 0.5 . Apex of first costal section not black, with two enlarged bristles. Third costal section with heavy bristles on its basal $1 / 3$.

Wing length about $2.0 \mathrm{~mm}$ ( $\hat{\delta}) ; 2.2 \mathrm{~mm} \mathrm{(q).}$

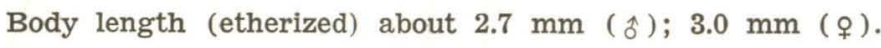

Internal characters of imagines and genitalia $(\hat{o})$ - Testis pale yellow with about 6 and 1/2 outer and 2 inner coils. Epandrium with about 25 lower and 3 upper bristles; toe strongly bent forward. Cerci fused at lower $1 / 3$. Surstylus with about 8 primary teeth and 15 marginal bristles (Fig. 2a); bridge as shown in Figure 2c.

Hypandrium longer than epandrium; concha of hypandrium bare, mostly membranous, fused to hypandrium and bearing one sclerotized finger-shaped process (Fig. 2d).

Aedeagus long, curved, noticeably assymetric (trifid) at tip; posterior end covered with tiny teeth; dorsal cleft about $1 / 2$ of length (Fig. 3). Aedeagal apodeme laterally flattened, broadly fused to ventral rod. Ventral rod posteriorly expanded. Gonopod absent. Phallosomal index about 6.0 .

(q) - Ovipositor with about 6 heavy black spines on posterior margin, three small bristles subapically on anterior margin, one large bristle located between ultimate and penultimate spine; posterior apex with about 3 sensilla (Fig. 2b). Spermathecae ball-shaped, weakly sclerotized, with no apical cap; duct not invaginated.

Eggs, puparia and chromosomes - Not studied.

Relationship - Belongs to the nesiota subgroup of the flavopilosa group of the subgenus Drosophila. It seems to be related to $D$. incompta Wheeler \& Takada from which it differs chiefly in the shape of aedeagus (Fig. 1), the structure of hypandrium and the number of spines of ovipositor. 
Distribution - The type-locality is the only site where this species has been collected.

Ecology - Breeds on flowers of Cestrum intermedium (Solanaceae).

Etymology - Named after Maria Helena Aguiar Ribeiro, one of the collectors of the flowers from which the type-series has been reared.

\section{Acknowledgments}

I wish to trank Dr. F. C. Val for the criticism of the manuscript; Dr. D. Brncic for suggesting this study; Miss L. Rossi and Miss L. d'A. Freire de Carvalho for identifying the Cestrum species and Miss S. M. Loureiro for reviewing the English manuscript. Dr. F. C. Val was kind enough to identify the Zygothrica specimens. This work was supported by FAPESP (Proc. biológicas 81/0483-9) and USP.

\section{References}

Brncic, D., 1978. A note on the flavopilosa group of Drosophila in Rio Grande do Sul, Brazil, with description of two new species (Diptera, Drosophilidae). Revta. bras. Biol. 38 (3) : 647-651.

Hsu, T. C., 1949. The external genital apparatus of male Drosophilidae in relation to systematics. Univ. Tex. Publs 4920: 80-142.

Kaneshiro, K. Y., 1969. A study of the relationships of Hawaiian Drosophila species based on external male genitalia. Ibid. 6918: 55-70.

Vilela, C. R., 1983. A revision of the Drosophila repleta species group (Diptera, Drosophilidae). Revta bras. Ent. 27 (1) : 1-114.

Wheeler, M. R. and M. P. Kambysellis, 1966. Notes on the Drosophilidae (Diptera) of Samoa. Univ. Tex. Publis 6615: 533-565.

Wheeler, M. R., H. Takada \& D. Brncic, 1962. The flavopilosa species group of Drosophila. Ibid. 6205: 395-413. 